\title{
KEY ISSUES IN 3D ROCKFALL MODELING, NATURAL HAZARD AND RISK ASSESSMENT FOR ROCKFALL PROTECTION IN HŘENSKO (CZECHIA)
}

\author{
Michal KUSÁK ${ }^{1)}$ *, Andrea VALAGUSSA ${ }^{2)}$ and PAOLO FRATTINI ${ }^{2)}$ \\ 1) Institute of Rock Structure and Mechanics, The Czech Academy of Sciences, \\ V Holešovičkách 41, 18209 Prague, Czech Republic \\ ${ }^{2)}$ University of Milano-Bicocca, Department of Earth and Environmental \\ Sciences, p.zza della Scienza 4, 20126 Milano, Italy
}

*Corresponding author's e-mail: kusak@irsm.cas.cz

\section{ARTICLE INFO}

Article history:

Received 2 May 2019

Accepted 27 August 2019

Available online 22 October 2019

\section{Keywords:}

Rockfall

3D modeling

Hazard

Risk

HY-STONE

Rockfall assesment

Dynamic Barriers

Hřensko (Czechia)

\begin{abstract}
The growing urban development in mountain areas together with climate change increased the need for rockfall research and modeling. Determining rockfall processes and related hazard is still a difficult task because of the complexity and intrinsic stochastic nature of the physics involved. In recent years, numerical simulations of rockfall trajectories became common procedure for evaluating rockfall hazard. Increasing of model accuracy leads to the need for more specific complex calibration, appropriate combination of rockfall modeling tools, as well as careful assessment of rockfall sources, block and slope characteristics. Rockfall modeling issues have been tested in local study areas in Hřensko (Czechia) through HY-STONE 3D software. The Hřensko area is characterised by sandstone landscape with rock plateaus, deep canyons with several levels of steep cliffs, which forms favourable conditions for rockfalls. Different modeling approaches, calibration problems, dependency of model results to parameters, and proposed appropriate countermeasures are discussed. The aim of this paper is to provide a knowledge base for researchers and practitioners involved in projects dealing with rockfall protection.
\end{abstract}

\section{INTRODUCTION}

Rockfalls pose a significant threat to life and property; therefore, the knowledge of these phenomena is necessary for land planning and risk mitigation. Rockfall can be defined as the downward movement of detached rock fragments (a single block, several blocks, or a fragmented mass of rock) by free falling, bouncing, rolling, and sliding (Cruden and Varnes, 1996; Volkwein et al., 2011; Crosta et al., 2015). Rockfalls are important hazard predominantly in mountainous areas and the number of the rockfall researches is relatively small with respect to other types of mass movements and landslides (Sassa et al., 2009). However, the need for urban development in mountain areas has leaded to an increase of the researches on rockfalls in the last decade (e.g.: Lambert and Bourrier, 2013; Olmedo et al., 2016).

Typically rockfalls are characterized by a long runout and high range of volumes ranging from few cubic centimeters to thousand of cubic meters (large boulders of $100 \mathrm{~m}^{3}$ in Loye at al., 2009). Due to their high velocities (up to tens of meters per second), even low magnitude events (boulder volume $<1 \mathrm{~m}^{3}$ ) may be highly destructive with the potential to cause fatalities (Fanos and Pradhan, 2019).

Rockfalls are natural disasters that can threaten isolated homes and entire villages, long stretches of roads and railways and other man-made facilities, which are situated on or close to the base of steep rocky slopes. Rockfall hazard assessment relies on the quantity and quality of available data (Fanos and Pradhan, 2019). Development of remote sensing techniques, geoinformation systems (GIS), techniques of light detection and ranging (LiDAR), and terrestrial laser scaning can create high resolution Digital Elevation Models (DEMs), that describe a surface topography with many details and small steps in the slope geometry (Volkwein et al., 2011). Due to this, significant advances in rockfall analysis have been made in the last decade.

High resolution DEMs are also used by new modern mathematical runout models, which calculate rockfall trajectories in $2 \mathrm{D}$ or $3 \mathrm{D}$ spatial framework with different sets of kinematic or dynamic equations of motion. 2D models are suitable where geometric and dynamic effects of the 3D topography can be ignored, such as on planar cliff - talus slopes, on slopes characterized by low roughness, and on slopes with little or no vegetation (Crosta and Agliardi, 2004; Volkwein et al., 2011). For rockfall problems with significant lateral dispersion, the 2D block trajectories introduce considerable uncertainty or even errors. In such context, 3D models that exploit the threedimensional form of the topography provided by 


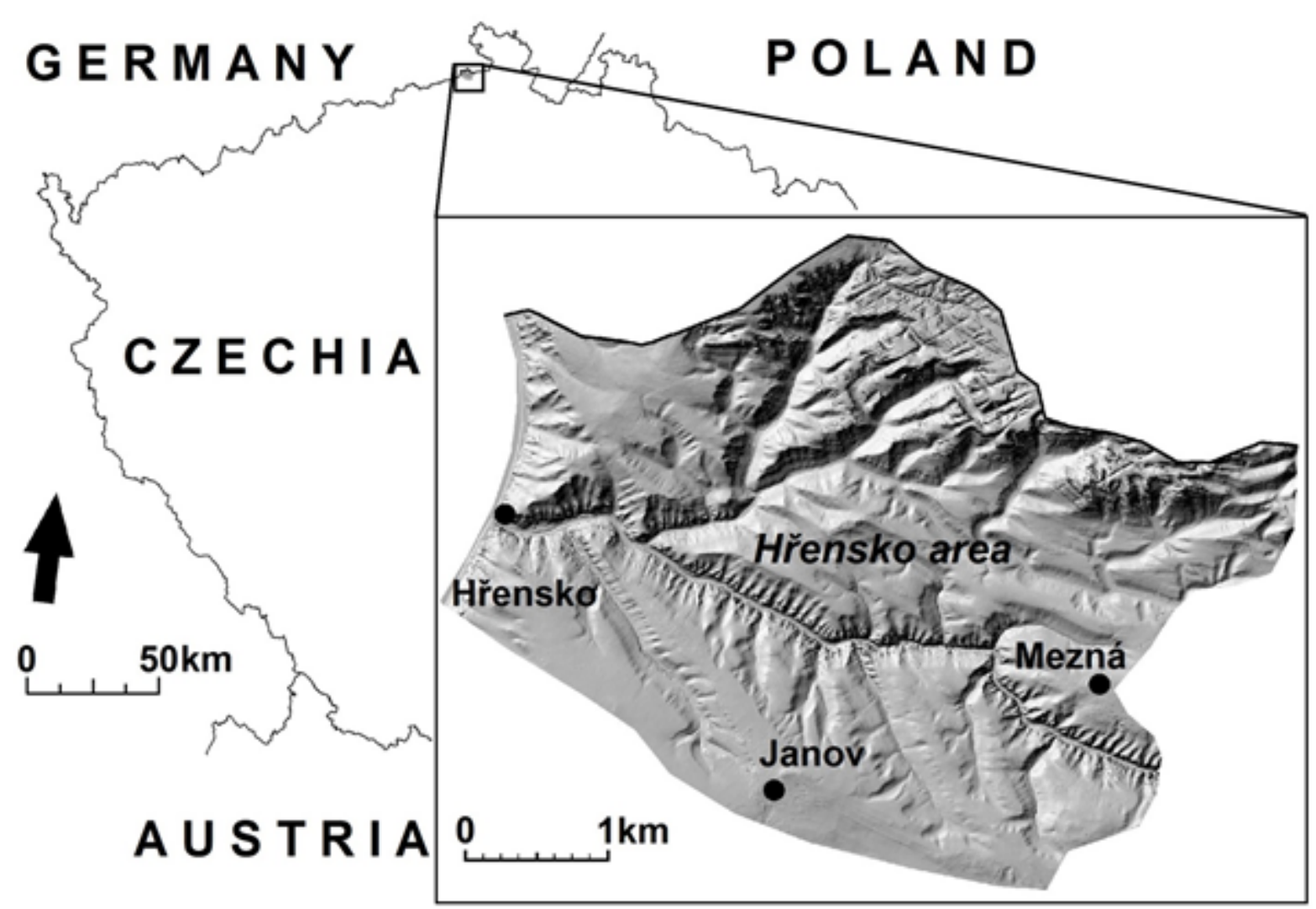

Fig. 1 Study area of Hřensko.

DEMs can be efficiently used for rockfall simulations (Guzzetti et al., 2002; Agliardi and Crosta, 2003; Crosta et al., 2004; Dorren et al., 2006; Lan et al., 2007).

Mathematical runout models provide accurate description of rockfall trajectories, velocity, energy, and fly height of blocks in each spatial element of the map. 3D models are able to simulate block motion along a slope by including lateral dispersion of trajectories due to large and small scale morphological complexity. The obtained results are spatially distributed over the entire study area, without any need for interpolation of data among specific trajectories or for imposing predetermined fall direction. However, due to the complexity and intrinsic stochastic nature of rockfall physics and the uncertainty of all the relevant parameters, 3D rockfall modeling is still difficult. Successful use of modeling programs requires a thorough understanding of their logic, assumptions, advantages and limitations, as well as careful assessment of rockfall sources, blocks and slope characteristics, and model calibration data (Frattini et al., 2012; Volkwein et al., 2018).

In this paper, the propagation of rockfalls (free fall, impact and rolling) has been simulated through HY-STONE 3D software (Crosta et al., 2004, 2015; Agliardi et al., 2009; Frattini et al., 2012, 2013; Dinçer et al., 2014; Valagussa et al., 2014).

The aim of this paper is to provide information about rockfall modeling and to present advantages and disadvantages of different methods to researchers and/or practitioners working in civil or environmental engineering and safety and involved in projects aimed at protecting structures and infrastructures against falling rocks. In particular, the paper focuses on how the variation of control parameters (such as landuse parameters calibration; changing of topographic roughness and DEM resolutions; fragmentation of falling blocks; presence of rockfall countermeasures) can influence the 3D rockfall modeling.

\section{STUDY AREA}

The study area $\left(19 \mathrm{~km}^{2}\right.$; Fig. 1) is located in Hřensko, which is part of the Bohemian Switzerland National Park (BSNP; area $79 \mathrm{~km}^{2}$ ) and it is an important tourist destination. The area is situated along the Elbe River Canyon in the Northwestern Czechia, next to the border with Germany (Fig. 1). Hřensko area is characterized by a sandstone landscape with rock plateaus, deep canyons with several levels of steeply cliffs and rock cities, which form favourable conditions for rockfalls (Kalvoda and Zvelebil, 1983; Tyráček, 2001; Vařilová and Zvelebil, 2007; Blahůt et al., 2013; Vařilová et al., 2014).

The current landscape is the result of the longterm dynamic development of the whole area (e.g. Kalvoda and Zvelebil, 1983; Vařilová and Zvelebil, 2007) and it is formed by rock slopes and dissected sandstones of the Late Cretaceous Age (Cenomanian, Lower and Middle Turonian Age) (Blahůt et al., 2013). These sandstones are part of the Bohemian Cretaceous Basin, which was eroded by repeated episodes of downward cutting of the Elbe River and its tributaries during lower and middle Pleistocene due to climatic and partially also tectonic conditions resulting in the development of a complex river terraces system (Kalvoda and Zvelebil, 1983). The Bohemian Cretaceous Basin consists predominantly 


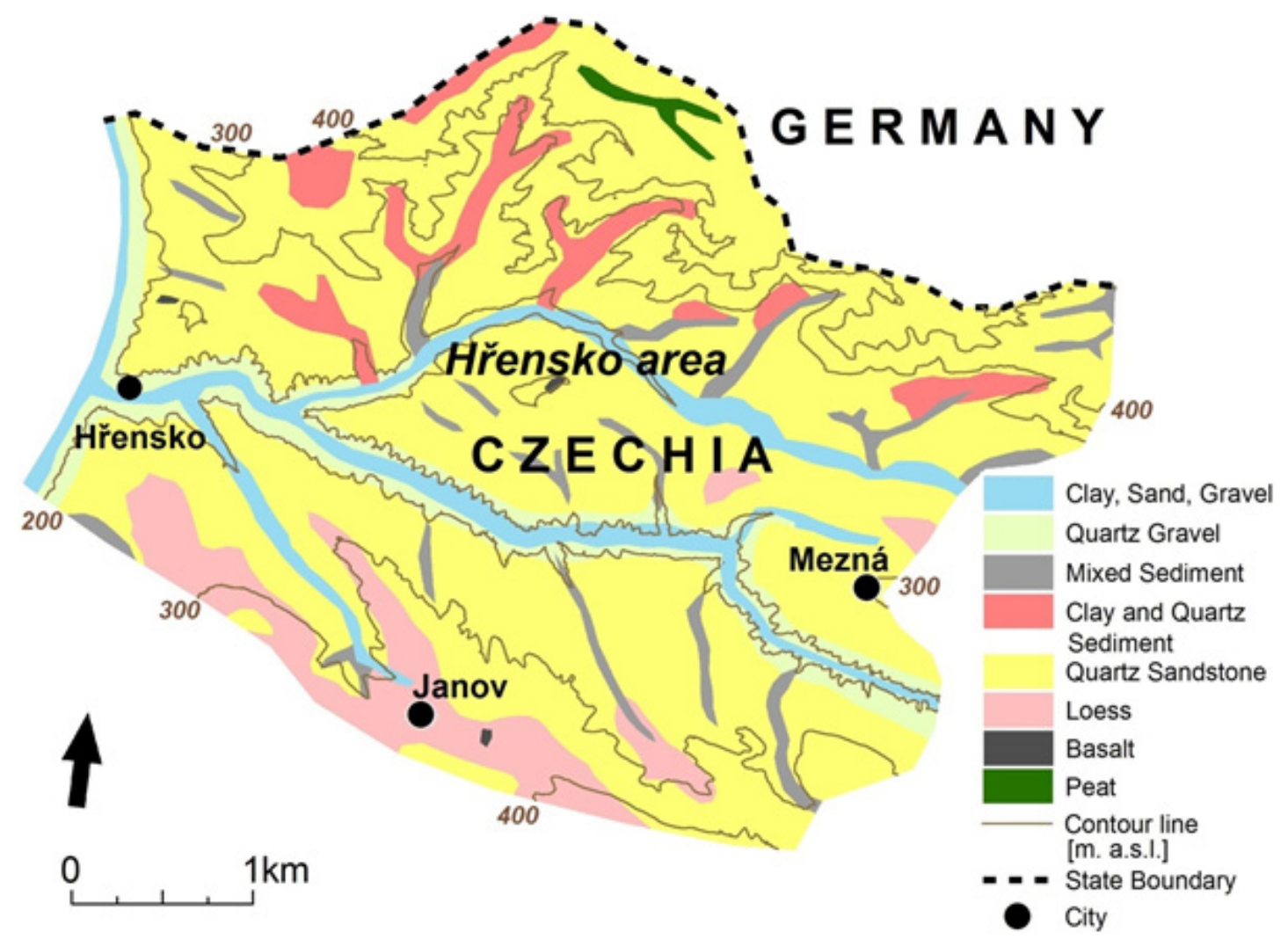

Fig. 2 Litotechnical map of Hřensko area (according to Czech Geology Survey, 1998).

of sandstone with a density of $2 \mathrm{ton} / \mathrm{m}^{3}$ (Petránek et al., 2016).

In the upper parts of tributary valleys there are layers of clay and quartz sediments, and mixed sediment layers in the lower parts (Fig. 2). These valleys are up to $200 \mathrm{~m}$ deep. Blahůt et al. (2013) also described deep canyons with uncovered crystalline basement rocks (e.g. outcrops of Paleozoic granitic rocks outcrop).

Valley slopes are characterized by several levels of cliffs with slope angle higher than $75^{\circ}$ and height from few meters to tens of meters. High and almost vertical rock cliffs as well as detached blocks on rims of plateaus create favourable conditions for geomorphic hazards occurrence connected with the various types of slope movements. In particular, the rockfalls of sandstone blocks represent a great danger for local inhabitants and infrastructures. Šafránek (2016) describes several dozen rockfall events with volume $\sim 1 \mathrm{~m}^{3}$ per year in the Bohemian Switzerland National Park (BSNP) and many other rockfall events with volume lower than $1 \mathrm{~m}^{3}$ in unavailable ares without rockfall monitoring. The larger rockfall events with volumes between $1 \mathrm{~m}^{3}$ and $10 \mathrm{~m}^{3}$ occur about once a year and rockfall events with volume higher than $10 \mathrm{~m}^{3}$ occur about once every 30 years (last in January 2002; Šafránek, 2016). The largest recorded rockfall events in Hřensko area include rockfalls in the years 1936 (volume $\sim 400 \mathrm{~m}^{3}$ ) and 1978 (volume $>2,000 \mathrm{~m}^{3}$ ) (Šafránek, 2016).

\section{METHODS}

In this work, the HY-STONE software (Agliardi and Crosta, 2003; Crosta et al., 2004) is used to explore possible approaches, problems and results of rockfall modeling. HY-STONE is based on a hybrid algorithm that is a modified version of the one proposed by Pfeiffer and Bowen (1989) and Azzoni et al. (1995). It exploits high resolution 3D topography and allows to simulate free fall, impact and rolling with different damping relationships available. The topography is described by a raster DEM, which is converted into a vector topographic model (Triangulate Regular Network) for the solution of impact and rolling (Guzzetti et al., 2003).

The capability to simulate the effect of passive countermeasures, the effect of block fragmentation and dynamics of "flying rocks" have been implemented and tested against real events (Frattini et al., 2012). The fragmentation along the cliff occurs when the energy of a block at impact exceeds a defined threshold following the relationship proposed by Yashima et al. (1987). The maximum number of fragments generated after fragmentation and their diameters are based on: (1) a factor $f$ that determine the maximum diameter obtained after fragmentation, (2) the number of different diameter classes $r d$, and (3) the exponent of the power-law curve $n$ that define the frequency distribution of the fragments (Wu et al., 2004). In this study $f=0.9$, $r d=2$, and $n=2$. After the impact, the maximum value of energy still available is calculated as the sum of translational and rotational energy. The kinetic energy is equally distributed among the fragments, and the velocity of each fragment is calculated from this kinetic energy and its mass. Hence, the smaller the fragment, the higher is the translational velocity. 


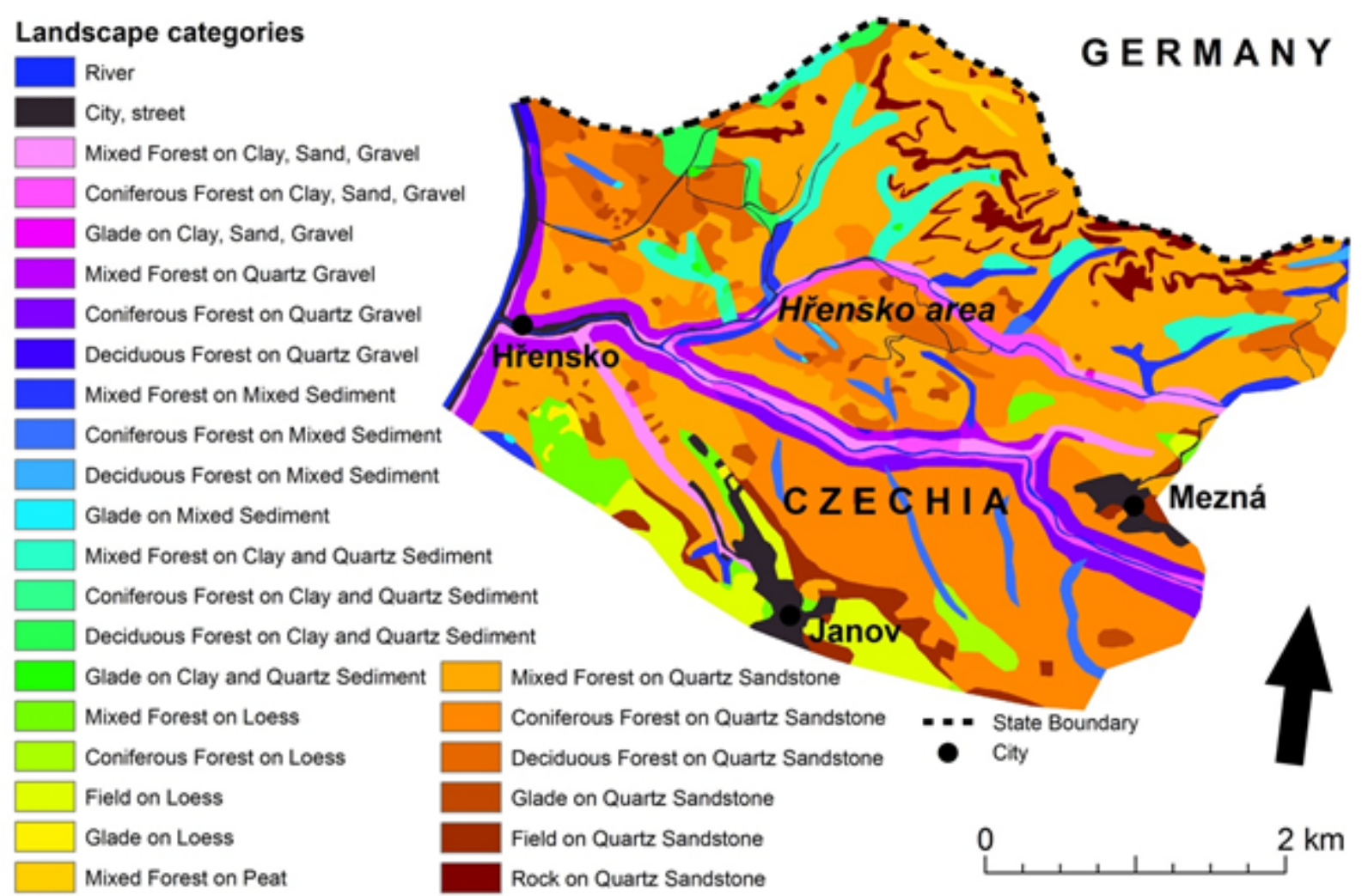

Fig. 3 Landscape categories of Hřensko area.

The rotational velocity is assumed equal to the reduced rotational velocity calculated by applying a reduction coefficient.

HY-STONE also includes the possibility to model the effects of vegetation to runout trajectories. In fact, vegetation (e.g. mixed forest) has significant effects on rockfall energy dissipation and trajectory. Fuhr at al. (2015) and Olmedo at al. (2016) described forests with density higher than 500 stems/ha as an efficient natural protection solution against rockfall. Modeling the effect of vegetation requires information about the density and position of trees on the slope, and their height and width (Evans et al., 2001; Koukoulas and Blackburn, 2005; Dorren et al., 2005; Crosta et al., 2006; Lundström et al., 2009). Dorren et al. (2006) found that the energy lost by impact on tree stems is greatest for central impacts, and decreases according away from the stem axis. This is realistic when the block is relatively small or similar in size to the width of the tree. If the block is much larger than the stem diameter, the falling block will be minimally affected by its impact on the tree (Leine et al., 2013). Further, Fuhr at al. (2015) developed a specific module to integrate deadwood into the $3 \mathrm{D}$ rockfall simulations, because large logs increase the surface roughness of the forest floor and act as additional obstacles to dropped blocks.

The simulation of energy loss on soft ground would be improved by soil layers informations. Prisco and Vecchiotti (2006) developed a visco-elastoplastic model for simulations of the response of homogeneous soil layers to the impact of spherical rigid boulders, which can be included into HYSTONE. For this model values of the soil parameters commonly used for geotechnical characterization of granular materials are used. The model provides the simulation of block displacement and the exit velocity vector, the dynamic load on the soil, and depth of penetration.

For the simulation of rockfalls in this paper, a high-resolution Digital Elevation Model (DEM) with pixel size of $1 \mathrm{~m}$ is used to describe topography.

The litotechnical informations (Fig. 2) were combined with landuse/landcover informations to define 27 different landscape categories of Hřensko area (Fig. 3), which were converted to raster. Three parameters were defined for each category: the normal and tangential restitution coefficients, which control the amount of energy lost by block at each impact in normal and tangential direction, and the rolling friction coefficient (i.e. the tangent of the dynamic rolling friction angle), which control the amount of energy lost by blocks rolling over the slope surface. All values were initially derived from the literature according to Frattini et al. (2012), and then calibrated by performing several simulation runs until model results agreed with actual historical deposits mapped in Hřensko area (Figs. 4a and 4c). This approach follows the reference for future rockfall analyses by Volkwein et al. (2018).

Rockfall deposits and blocks for past rockfall events were mapped on the field around hiking trail Gabrielina stezka on the bottom of valley Dlouhý důl. These deposits and blocks will be used for the backcalibration of the model parameters.

Three types of rockfall sources were mapped in the study area to be used for different purposes. (1) In order to calibrate the model parameters and to analyse the effect of topographic roughness and fragmentation, linear rockfall sources were mapped on 


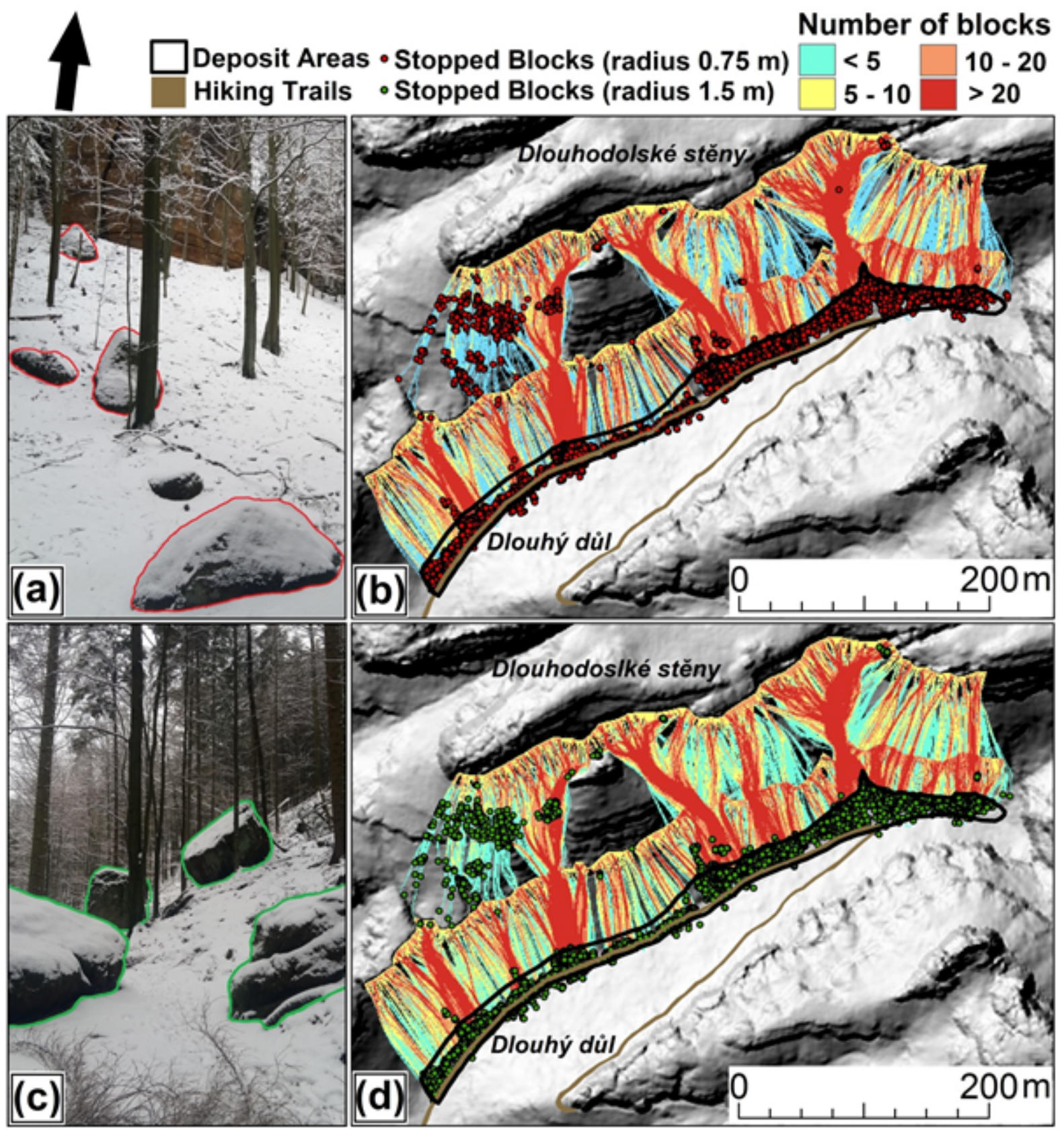

Fig. 4 (a) mapped actual blocks with radius $\sim 0.75 \mathrm{~m}$ in deposit area; (b) rockfall simulations with block radius $0.75 \mathrm{~m}$; (c) mapped actual blocks with radius $\sim 1.50 \mathrm{~m}$ in deposit area; (d) rockfall simulations with block radius $1.50 \mathrm{~m}$.

the upper edge of cliffs with slopes $>75^{\circ}$ around hiking trail Gabrielina stezka between valleys Dlouhodolský důl, Pravčický důl and Černý důl. The same type of rockfall sources was used to test countermeasures efficency on the cliffs surrounding Hřensko city. (2) Rockfall point-like sources and areal sources (areas with slope gradient $>75^{\circ}$ ) were mapped on the cliffs around hiking trail Gabrielina stezka between valleys Dlouhodolský důl, Pravčický důl and Černý důl to be used to get more details about the variation of rockfall trajectories and block fragmentation. For rockfall sources (1) and (2), the onset probability (i.e. relative spatial probability of rockfall onset from each source cell) was set to $100(\%)$ for each source cell. (3) For the final rockfall analysis and the proposal of countermeasures, areal rockfall sources were mapped on field mapping around the main roads and hiking trails of the study areas. These rockfall sources have a defined size (height and width) and they have been classified into three categories of different onset probability: $100 \%$ for overhanging walls, $75 \%$ for cliffs, and $50 \%$ for rock plates.

\section{RESULT}

\subsection{MODEL CALIBRATION}

The model parameters were calibrated by back analysis, through the comparison of the simulation results with field mapping of actual older rockfall deposits around hiking trail Gabrielina stezka on the bottom of valley Dlouhý důl. The mapped deposits area (500 m long; $30 \mathrm{~m}$ wide) was formed mostly of blocks with a radius ranging between $0.75 \mathrm{~m}$ and $1.5 \mathrm{~m}$ (Figs. $4 \mathrm{a}$ and $4 \mathrm{c}$ respectively). Two levels of 


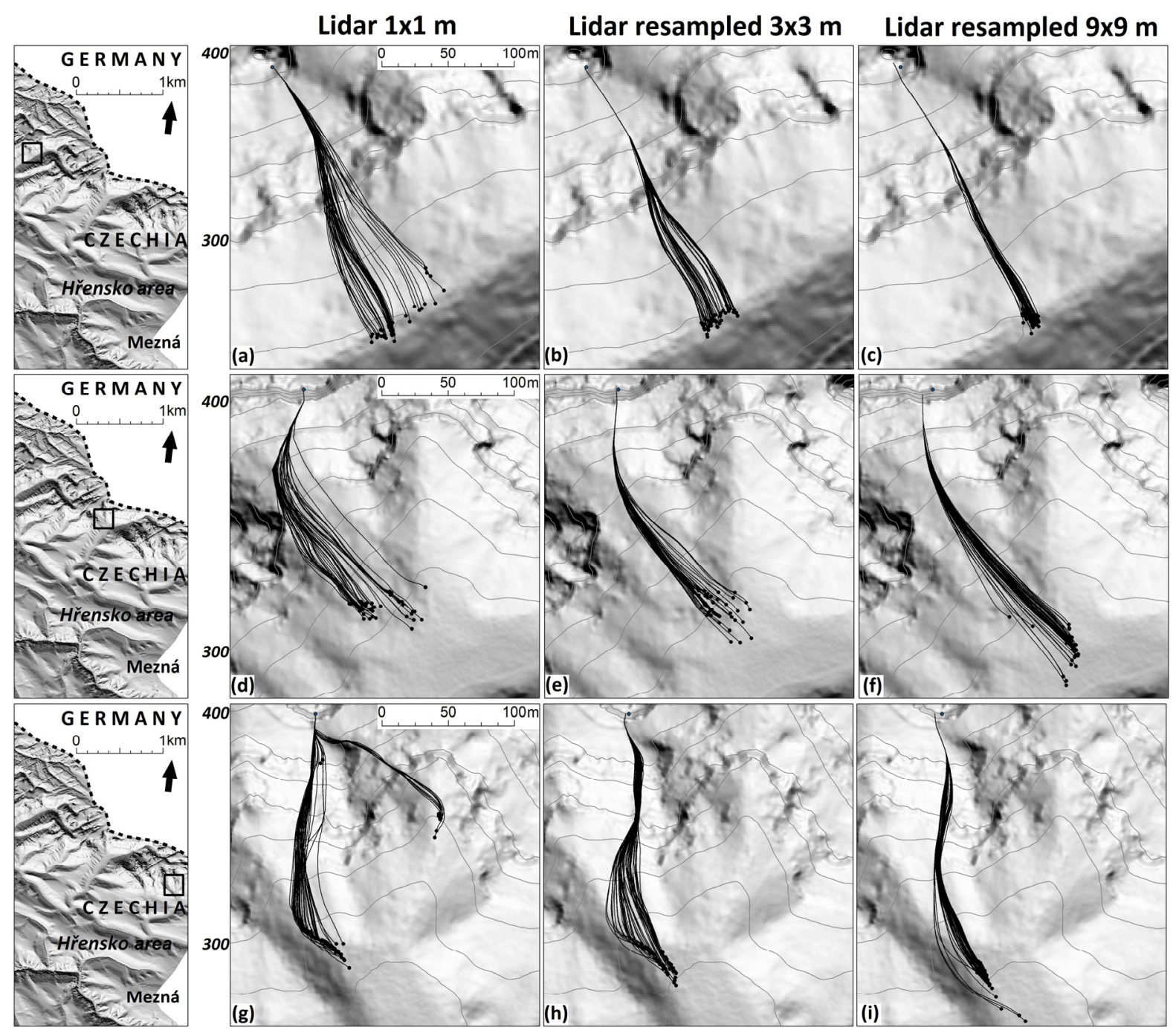

Fig. $53 \mathrm{D}$ runout simulations performed using topographic descriptions (Digital Elevation Models) at different resolution: $1 \mathrm{~m}(\mathrm{a}, \mathrm{d}, \mathrm{g}) ; 3 \mathrm{~m}(\mathrm{~b}, \mathrm{e}, \mathrm{h})$, and $9 \mathrm{~m}(\mathrm{c}, \mathrm{f}, \mathrm{i})$. For each case of rockfall were simulated falls of 50 blocks with block radius $=1.5 \mathrm{~m}$ were simulated.

rockfall sources were defined on Dlouhodolské stěny cliff (Figs. 4b and 4c; 5b and 5c): the lower cliff level $(80 \mathrm{~m}$ from the hiking trail with $50 \mathrm{~m}$ height difference) and the higher cliff level (150 $\mathrm{m}$ from the hiking trail with $170 \mathrm{~m}$ height difference). For all the cases, ten blocks were simulated from each pixel sources area.

During the 3D simulations, more than $92 \%$ of dropped blocks were stopped in mapped deposit area (96\% from lower cliff level and $87 \%$ from higher cliff level; Table 1). According to Frattini et al. (2012), a simulation result can be considered as good if $90 \%$ of the simulated blocks fall within a slope segment where the actual blocks stopped. Most of the dropped blocks from the higher cliff level which did not reach the mapped deposit area stopped between two cliff's edges, where the slope angle is lower than $20^{\circ}$. Conversely, some simulated blocks stopped uphill from the border of deposit area (Fig. 4).

\subsection{TOPOGRAPHIC MODEL RESOLUTION}

The dependence of runout pattern on DEM resolution was tested in some study areas in Hřensko by resampling the original DEM with pixel size $1 \mathrm{~m}$ to
$3 \mathrm{~m}$ and $9 \mathrm{~m}$ (Figs. 5 and 6). Rockfall runout simulations of point-like source areas clearly document a sharp reduction in lateral dispersion as DEM resolution decreases (Fig. 5).

When using areal rockfall sources (slope angle $>$ $75^{\circ}$ ), the rockfall runout simulations document an increase of simulated runout distance as DEM resolution decreases (Fig. 6).

\subsection{BLOCK FRAGMENTATION}

The effect of fragmentation was tested in several study areas in Hřensko. The comparison of simulation with and without fragmentaion in Hřensko area shows that block fragmentation has an effect on the properties of falling blocks (Fig. 7).

As expected, the number of blocks increases significantly after the fragmentation. This process also produces flying rocks or rock splinters with very high velocities. These flying rocks change their trajectories from the straight-line parent block trajectory to cover a wide angle from the fragmentation point. Therefore, block fragmentation changes the runout extent and on the spatial distribution of velocities and relative heights of the flying rocks. 
Table 1 Rockfall information of valley Dlouhý důl.

\begin{tabular}{lccccc}
\hline $\begin{array}{l}\text { Rockfall } \\
\text { sources }\end{array}$ & $\begin{array}{c}\text { Block } \\
\text { radius [m] }\end{array}$ & $\begin{array}{c}\text { Total number of } \\
\text { simulated blocks }\end{array}$ & $\begin{array}{c}\text { Block stopped in } \\
\text { deposit area }\end{array}$ & $\begin{array}{c}\text { Block stopped } \\
\text { before deposit } \\
\text { area }\end{array}$ & $\begin{array}{c}\text { Block stopped } \\
\text { after a deposit } \\
\text { area }\end{array}$ \\
\cline { 2 - 6 } Lower & 0.75 & $8,099(100 \%)$ & $7,831(96.69 \%)$ & $127(1.57 \%)$ & $141(1.74 \%)$ \\
cliff level & 1.50 & $8,099(100 \%)$ & $7,784(96.11 \%)$ & $144(1.78 \%)$ & $171(2.11 \%)$ \\
Higher & 0.75 & $6,709(100 \%)$ & $5,867(87.55 \%)$ & $815(12.15 \%)$ & $27(0.40 \%)$ \\
cliff level & 1.50 & $6,709(100 \%)$ & $5,927(88.31 \%)$ & $756(11.27 \%)$ & $28(0.42 \%)$ \\
\hline
\end{tabular}

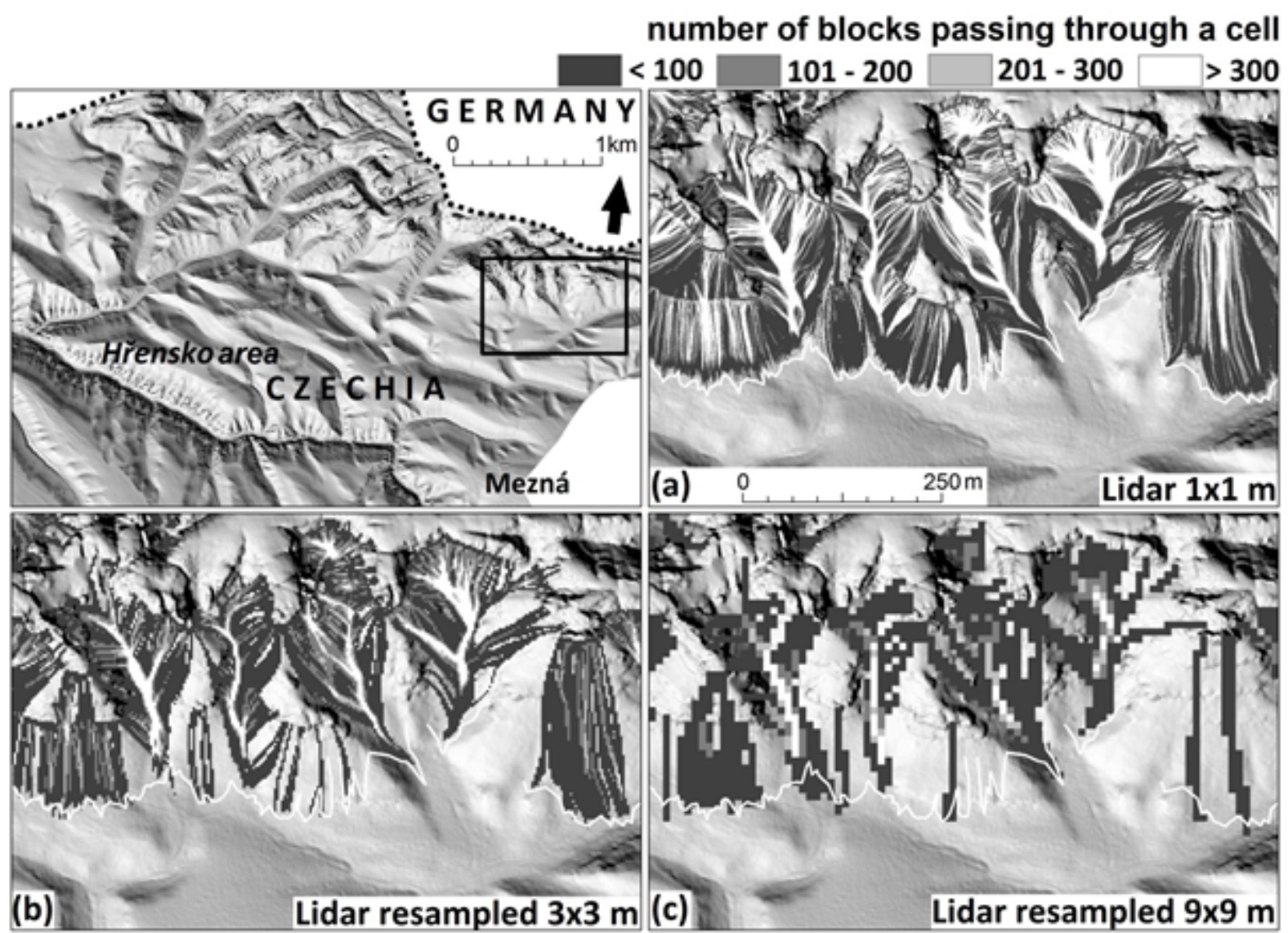

Fig. 6 3D rockfall modeling with (a) pixel size $1 \times 1 \mathrm{~m}$ and with DEMs obtained by resampling the original DEM at resolutions of (b) $3 \times 3 \mathrm{~m}$, and (c) $9 \times 9 \mathrm{~m}$. For each case 50 blocks were simulated from each source with a radius of $1.5 \mathrm{~m}$.

\subsection{ROCKFALL COUNTERMEASURE DESIGN AND OPTIMIZATION}

In 2015, rockfall barriers were installed in Hřensko area. These barriers are $4 \mathrm{~m}$ high and their total length is $2.5 \mathrm{~km}$. To test the effectiveness of these barriers around Hrrensko city, the rockfall sources were defined as the upper edge of cliffs with slope angle $>75^{\circ}$.

Following the simulation of a one falling block with radius $0.75 \mathrm{~m}$ from each pixel of cliff's edges (linear sources), the barriers captured 328 dropped blocks and only 6 blocks passed (Table 2). Therefore the barriers were effective at more than $98 \%$. Unfortunately, some blocks missed the barriers (mainly between nets n. 5 and 6; Fig. 8b) and the Hřensko city was threatened by $4.3 \%$ of simulated blocks.

The increasing of event frequency and probability of multiple impacts to the same place were simulated by launching 10 falling blocks with radius $0.75 \mathrm{~m}$ from each pixel of cliff's edges. Nets captured
3,307 blocks and only 43 blocks passed (Table 2), giving an effectiveness of more than $98 \%$ (Fig. 8b). However, the simulations of blocks with radius equal to $1.5 \mathrm{~m}$ (increasing kinetic energy) showed that the barriers captured 243 blocks and 90 blocks passed (Table 2), with an effectiveness of $63 \%$. As expected, the effectiveness of barriers decreases dramatically when size and kinetic energy of the blocks increase.

\subsection{COMPLEX ROCKFALL ANALYSIS OF THREE LOCATIONS IN H $\breve{R E N S K O ~}$}

After calibrating the model parameters and testing some of the main issues in rockfall modeling, a rockfall analysis and a proposal of countermeasures in three different locations of Hřensko area were carried out (Fig. 9). Three different types of potential source areas with different onset probability were detected through field mapping (Table 3). Based on field mapping, blocks from overhangs and cliffs were simulated as spheres (radius of $0.75 \mathrm{~m}$ ), while blocks falling from rock plates were simulated as disks 

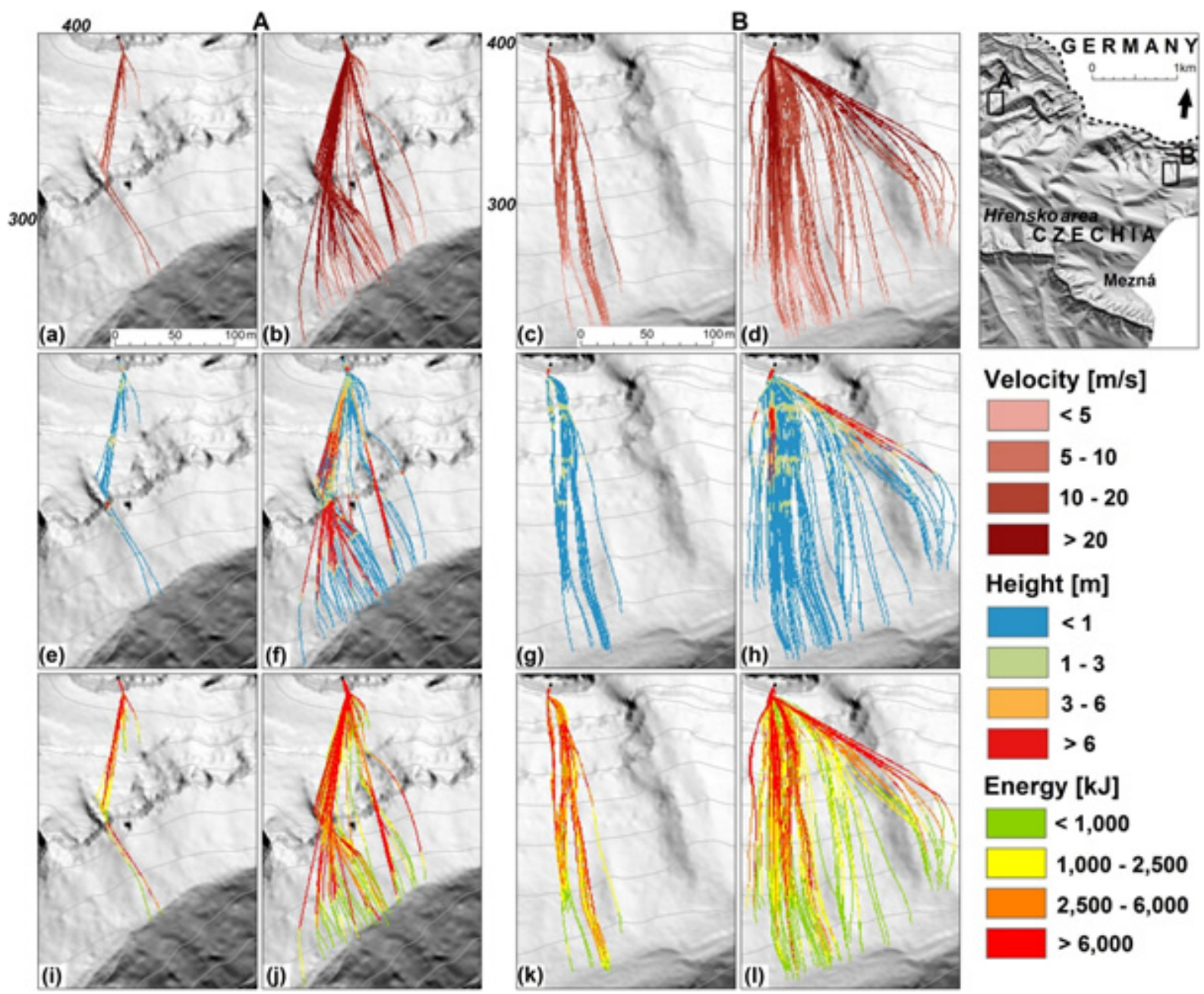

Fig. 7 Examples of 3D runout simulations without fragmentation(a, c, e, g, i, k), and simulations accounting for block fragmentation ( $b, d, f, h, j, l)$ in Hřensko area. For each case of rockfall falling blocks velocity $(\mathrm{a}-\mathrm{d})$, height $(\mathrm{e}-\mathrm{h})$ and energy $(\mathrm{i}-\mathrm{l})$ were calculated. 30 blocks with block radius $1.5 \mathrm{~m}$ were simulated from each source cell.

(radius of $0.75 \mathrm{~m}$; thickness $0.3 \mathrm{~m}$ ). 10 blocks were simulated from each source cell.

The first location is the parking place near the Hřensko city with part of road going from Hřensko to Mezná city. New flexible barriers with an absorption energy of $5000 \mathrm{~kJ}$ were installed on the rocks around the parking place ( $295 \mathrm{~m}$ long and $4 \mathrm{~m}$ high). On these rocks, thirteen potential source areas with different probability (ten cliffs, two rock plates and one overhang) were detected by field mapping. In case of a rockfall event, the installed barriers should be able to stop most of the falling blocks (Fig. 10a). Few blocks are missed or passed through nets, potentially hitting the road. The analysis of the kinetic energy of these blocks shows that in every damaged road section some of the blocks can hit the roads with energy exceeding 5,000 kJ (Fig. 10b), potentially passing through other barriers.

The second location is part of road from Hřensko to Janov city. On the cliffs around the area, seventeen potential source areas with different probability (seven overhangs, seven cliffs, and three rock plates) were detected by field mapping. Rockfall barriers were not installed on these cliffs, so most of the simulated blocks reach the road (Fig. 11a).
The third location is part of Gabrielina stezka hiking trail. On the cliffs around the area, ten potential source areas with different probability (four overhangs, four cliffs, and two rock plates) were detected by field mapping. During the simulation $\sim 20 \%$ of the falling blocks exceeded $5,000 \mathrm{~kJ}$ and $\sim 3-9 \%$ of simulated blocks exceeded $4 \mathrm{~m}$ (events marked as E, F, G in Figs. 12b, c). The hiking trails in the lower parts of valley were not threatened.

\section{DISCUSSION}

\subsection{MODEL CALIBRATION}

Model calibration is a fundamental step for rockfall modeling, and strongly controls the reliability of the results of any modeling scenarios. Several authors (Wong et al., 2000; Chau et al., 2002; Labiouse and Heidenreich, 2009) tried to derive accurate values for model parameters through experimental observations and numerical models of laboratory or in-situ rockfall tests. Nevertheless, in a real-scale application, the uncertainties about the boulder and slope properties can severly affect the rockfall behaviour. For example, the friction parameters of rock on quartz sandstone is controlled by local rock strength (weathering, structure, 
Table 2 Effectiveness testing of barriers around Hřensko city.

\begin{tabular}{|c|c|c|c|c|c|c|}
\hline \multirow{4}{*}{$\begin{array}{l}\text { Total number of blocks } \\
\text { Block stopped before } \\
\text { barriers } \\
\text { Flexible barriers }\end{array}$} & \multirow{2}{*}{\multicolumn{2}{|c|}{$\begin{array}{c}\mathbf{1} \text { block (radius } \mathbf{0 . 7 5} \mathbf{~ m} \text { ) } \\
\text { of each pixel source }\end{array}$}} & \multicolumn{2}{|c|}{$\begin{array}{c}10 \text { blocks (radius } 0.75 \mathrm{~m} \text { ) } \\
\text { of each pixel source }\end{array}$} & \multicolumn{2}{|c|}{$\begin{array}{l}1 \text { block (radius } 1.5 \mathrm{~m} \text { ) } \\
\text { of each pixel source }\end{array}$} \\
\hline & & & & 740 & & 374 \\
\hline & \multicolumn{2}{|c|}{24} & \multicolumn{2}{|c|}{285} & \multicolumn{2}{|r|}{30} \\
\hline & $\begin{array}{c}\text { Captured } \\
\text { blocks }\end{array}$ & $\begin{array}{l}\text { Uncaptured } \\
\text { blocks }\end{array}$ & $\begin{array}{c}\text { Captured } \\
\text { blocks }\end{array}$ & $\begin{array}{c}\text { Uncaptured } \\
\text { blocks }\end{array}$ & $\begin{array}{c}\text { Captured } \\
\text { blocks }\end{array}$ & $\begin{array}{c}\text { Uncaptured } \\
\text { blocks }\end{array}$ \\
\hline Net n. 1 & 23 & - & 220 & 2 & 20 & 3 \\
\hline Net n. 2 & 44 & 3 & 473 & 18 & 21 & 27 \\
\hline Net n. 3 & 27 & - & 246 & 3 & 14 & 2 \\
\hline Net n. 4 & 103 & 1 & 1,016 & 5 & 90 & 21 \\
\hline Net n. 5 & 17 & - & 153 & - & 13 & 2 \\
\hline Net n. 6 & 38 & 1 & 389 & 2 & 34 & 2 \\
\hline Net n. 7 & 29 & - & 286 & 3 & 17 & 15 \\
\hline Net n. 8 & 46 & 1 & 461 & 10 & 26 & 16 \\
\hline Net n. 9 & 7 & - & 63 & - & 8 & 2 \\
\hline Total & 328 & 6 & 3,307 & 43 & 243 & 90 \\
\hline $\begin{array}{l}\text { Blocks missing the } \\
\text { barriers }\end{array}$ & \multicolumn{2}{|c|}{10} & \multicolumn{2}{|c|}{105} & \multicolumn{2}{|c|}{11} \\
\hline Blocks threatening the city & \multicolumn{2}{|c|}{$16(4.3 \%)$} & \multicolumn{2}{|c|}{$148(4.0 \%)$} & \multicolumn{2}{|c|}{$101(27.0 \%)$} \\
\hline
\end{tabular}
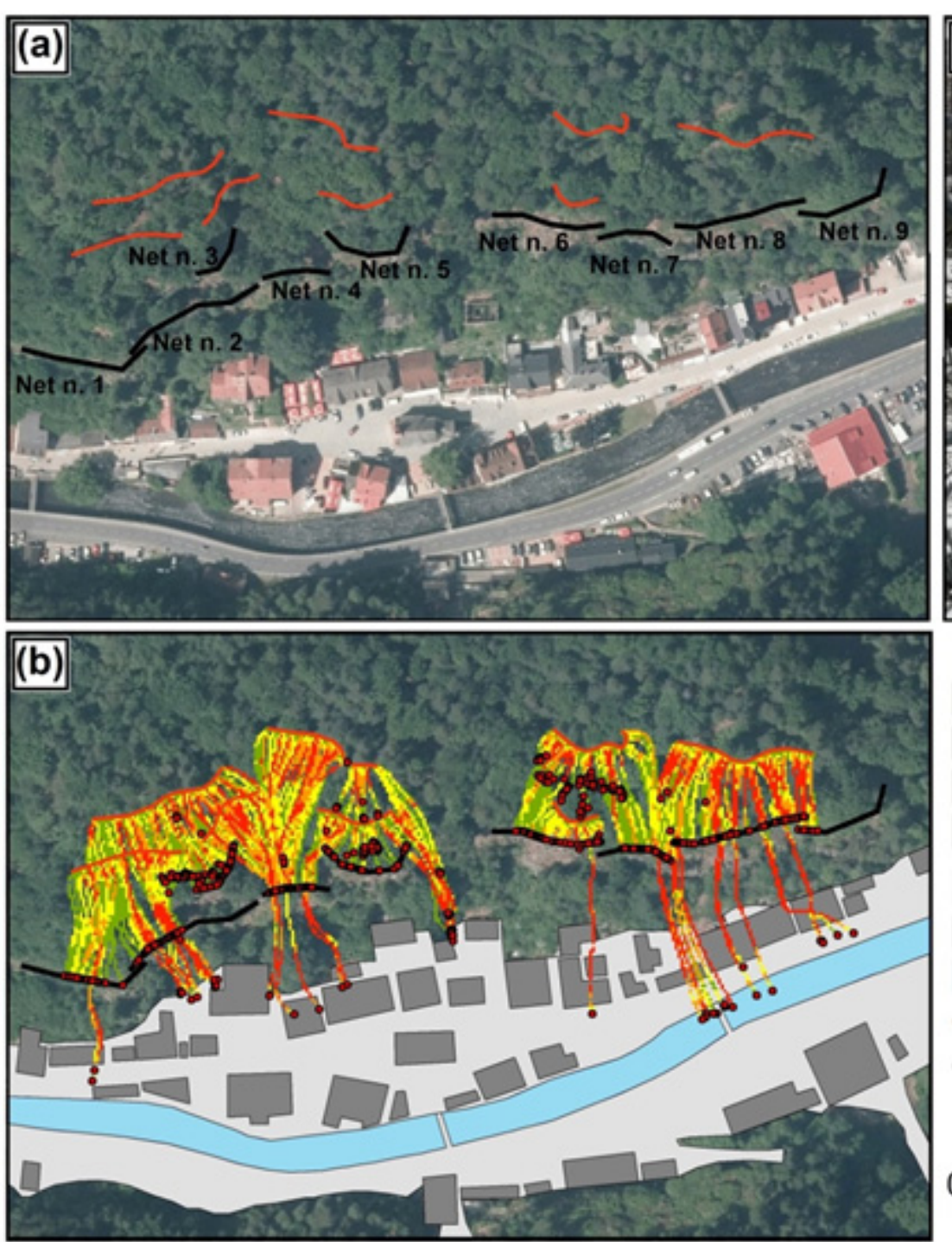

Fig. 8 Effectiveness testing of barriers around Hřensko city: (a) Hřensko city with the linear rockfall sources and barriers; (b) energy of falling blocks ( 10 falling blocks with radius $0.75 \mathrm{~m}$ from each pixel of cliff's edges); (c) nets in Hřensko area consisting of the main barriers and secondary meshwork. 


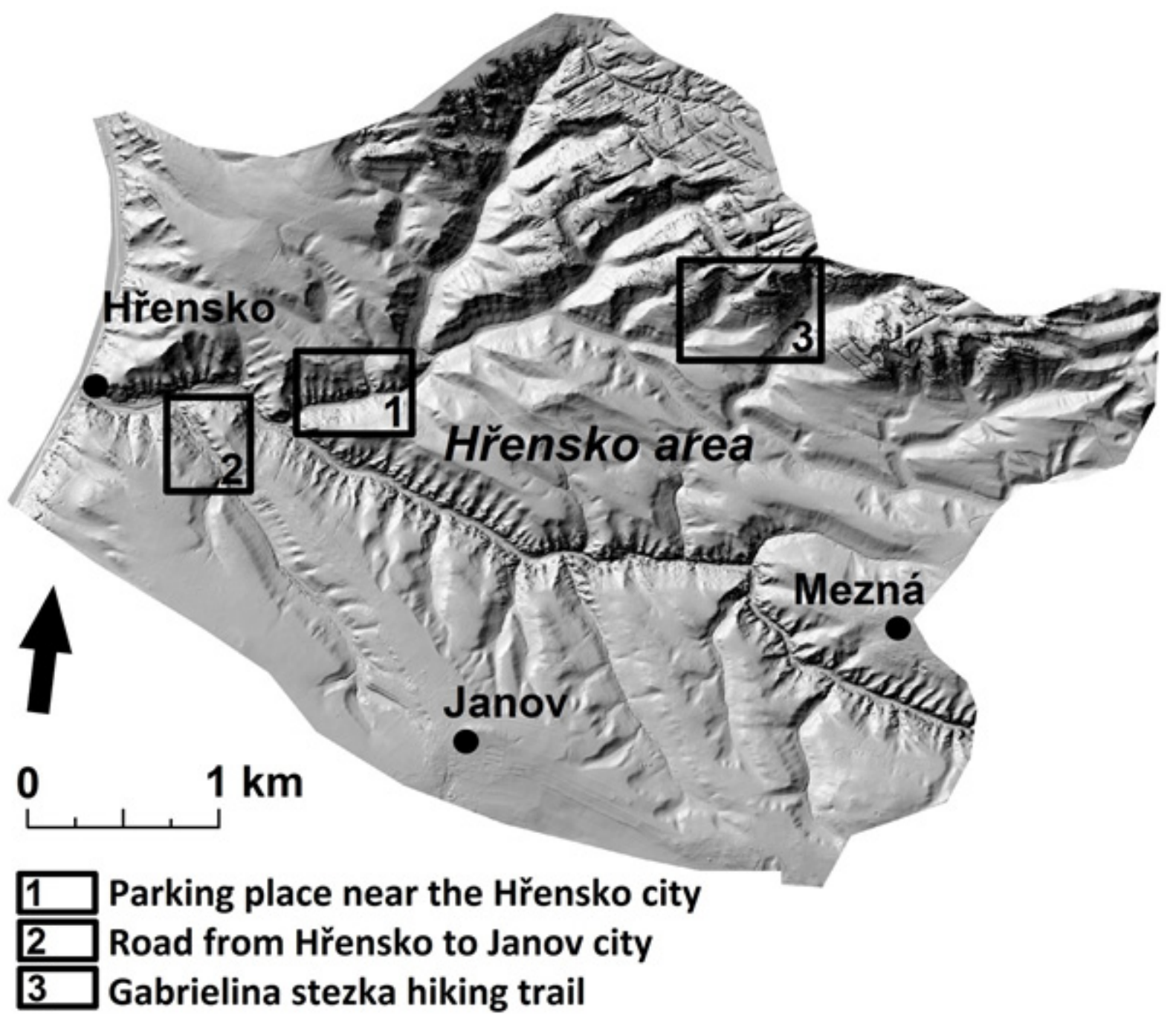

Fig. 9 Localization of the three study areas in Hřensko used for rockfall analysis and a proposal of possible countermeasures.

discontinuities, presence of pore water) taht cannot be characterized with an extreme detail when working at local to regional scale. Therefore, due to technical and budget constraints, the model parameters cannot be reasonabily determined through laboratory experiments. Therefore, model parameters are usually calibrated by expert knowledge or by back-analysis of past events. In this research, the area of valley Dlouhý důl and cliff Dlouhodolské stěny has been subdivided into three landscape categories for calibration: quartz sandstone (cliffs), mixed forest on quartz sandstone (valley slopes) and mixed forest on clay and quartz sediment (valley bottom). Trial and error repeated simulations allowed to tune the parameter values in order to reach a significant agreement between the simulated trajectories and the mapped rockfall events. Field activity results a valuable tool for rockfall modeling calibration and for the characterization of rockfall input data.

\subsection{EFFECT OF TOPOGRAPHIC MODEL RESOLUTION}

Rockfall runout simulations of point-like source areas (Fig. 5) and areal rockfall sources (slope angle $>$ $75^{\circ}$; Fig. 6) clearly document a sharp reduction in lateral dispersion as DEM resolution decreases. The higher resolution of topographic roughness (smaller pixel sizes of DEM) creates an increasing chaotic trajectories and the lateral dispersion of falling blocks. On the contrary, larger pixel sizes of DEM cause the smoothing effect, which influences the calibrated coefficients of restitution and friction. This smoothing causes a reduction of energy loss component of falling blocks, leading to longer rockfall trajectories.

The DEM roughness at different resolutions as well as the input values causes changes of rockfall trajectories. As a consequence, for the different DEMs resolutions it is necessary to use unique sets of input values (model calibration) to obtain the same pattern of impact marks and the same runout, 3D trajectory, and motion (bouncing, rolling and sliding). This point further supports the need for back-calibration of model parameters and the impossibility to obtain these values from experiments or laboratory tests.

\subsection{EFFECT OF BLOCK FRAGMENTATION}

As expected, the explicit simulation of fragmentation increases the number of blocks and cause a significant change in their original trajectories, runout extent, velocities and relative heights of the 
Table 3 Rockfall information of three locations in Hřensko

\begin{tabular}{|c|c|c|c|c|c|c|}
\hline Location & $\begin{array}{c}\text { Rockfall } \\
\text { event }\end{array}$ & $\begin{array}{c}\text { Type of } \\
\text { rockfall } \\
\text { source } \\
\end{array}$ & $\begin{array}{c}\text { Height } x \text { Width } \\
\text { [m] of rockfall } \\
\text { source } \\
\end{array}$ & $\begin{array}{l}\text { Block } \\
\text { shape }\end{array}$ & $\begin{array}{c}\text { Radius x } \\
\text { Thickness [m] of } \\
\text { falling blocks } \\
\end{array}$ & $\begin{array}{c}\text { Onset } \\
\text { Probability } \\
{[\%]} \\
\end{array}$ \\
\hline Parking place & 1 & Cliff & $14 \times 27$ & Sphere & 0.75 & 75 \\
\hline with road & 2 & Cliff & $9 \times 15$ & Sphere & 0.75 & 75 \\
\hline going from & 3 & Cliff & $6 \times 12$ & Sphere & 0.75 & 75 \\
\hline Hřensko to & 4 & Cliff & $7 \times 10$ & Sphere & 0.75 & 75 \\
\hline \multirow[t]{9}{*}{ Mezná } & 5 & Cliff & $5 \times 12$ & Sphere & 0.75 & 75 \\
\hline & 6 & Cliff & $8 \times 21$ & Sphere & 0.75 & 75 \\
\hline & 7 & Cliff & $10 \times 45$ & Sphere & 0.75 & 75 \\
\hline & 8 & Cliff & $9 \times 56$ & Sphere & 0.75 & 75 \\
\hline & 9 & Cliff & $10 \times 44$ & Sphere & 0.75 & 75 \\
\hline & 10 & Cliff & $7 \times 42$ & Sphere & 0.75 & 75 \\
\hline & 11 & Overhang & $8 \times 17$ & Sphere & 0.75 & 100 \\
\hline & 12 & Plate & $2 \times 16$ & Disk & $0.75 \times 0.3$ & 50 \\
\hline & 13 & Plate & $3 \times 13$ & Disk & $0.75 \times 0.3$ & 50 \\
\hline Road from & 1 & Overhang & $2 \times 3$ & Sphere & 0.75 & 100 \\
\hline Hřensko to & 2 & Overhang & $2 \times 5$ & Sphere & 0.75 & 100 \\
\hline \multirow[t]{15}{*}{ Janov } & 3 & Plate & $1 \times 5$ & Disk & $0.75 \times 0.3$ & 50 \\
\hline & 4 & Overhang & $3 \times 4$ & Sphere & 0.75 & 100 \\
\hline & 5 & Cliff & $4 \times 5$ & Sphere & 0.75 & 75 \\
\hline & 6 & Overhang & $2 \times 9$ & Sphere & 0.75 & 100 \\
\hline & 7 & Overhang & $4 \times 3$ & Sphere & 0.75 & 100 \\
\hline & 8 & Plate & $1 \times 4$ & Disk & $0.75 \times 0.3$ & 50 \\
\hline & 9 & Plate & $2 \times 17$ & Disk & $0.75 \times 0.3$ & 50 \\
\hline & 10 & Overhang & $3 \times 3$ & Sphere & 0.75 & 100 \\
\hline & 11 & Cliff & $5 \times 6$ & Sphere & 0.75 & 75 \\
\hline & 12 & Cliff & $5 \times 9$ & Sphere & 0.75 & 75 \\
\hline & 13 & Cliff & $4 \times 7$ & Sphere & 0.75 & 75 \\
\hline & 14 & Overhang & $2 \times 4$ & Sphere & 0.75 & 100 \\
\hline & 15 & Cliff & $9 \times 56$ & Sphere & 0.75 & 75 \\
\hline & 16 & Cliff & $10 \times 44$ & Sphere & 0.75 & 75 \\
\hline & 17 & Cliff & $7 \times 42$ & Sphere & 0.75 & 75 \\
\hline \multirow{10}{*}{$\begin{array}{l}\text { Hiking Trail } \\
\text { Gabrielina } \\
\text { stezka }\end{array}$} & 1 & Overhang & $4 \times 15$ & Sphere & 0.75 & 100 \\
\hline & 2 & Overhang & $3 \times 12$ & Sphere & 0.75 & 100 \\
\hline & 3 & Overhang & $4 \times 23$ & Sphere & 0.75 & 100 \\
\hline & 4 & Cliff & $7 \times 15$ & Sphere & 0.75 & 75 \\
\hline & 5 & Plate & $3 \times 8$ & Disk & $0.75 \times 0.3$ & 50 \\
\hline & 6 & Plate & $4 \times 13$ & Disk & $0.75 \times 0.3$ & 50 \\
\hline & 7 & Cliff & $5 \times 52$ & Sphere & 0.75 & 75 \\
\hline & 8 & Overhang & $4 \times 9$ & Sphere & 0.75 & 100 \\
\hline & 9 & Cliff & $7 \times 13$ & Sphere & 0.75 & 75 \\
\hline & 10 & Cliff & $2 \times 14$ & Sphere & 0.75 & 75 \\
\hline
\end{tabular}

flying blocks. The increase of heights and velocities of new flying fragments and rock splinters immediately after fragmentation is also connected with an increase of their runout extent. After the impact, available energy (i.e. kinetic energy of blocks minus energy lost at impact) is equally distributed among all new fragments and the velocity of each fragment is calculated from this kinetic energy and its mass (i.e. smaller fragment will have higher velocity). Blahůt et al. (2013) underline how in some cases the fragmentation of rock blocks may cause overestimation of the kinetic energy by the model. However, due to lower weight of these fragments, energy decreases rapidly with respect to the intact blocks (Figs. 7i, j, k and 1).
The fragmentation process and the probability of fragmentation occurrence are influenced by (1) starting block size; (2) block velocity; (3) rock strength and elastic properties of block and bedrock; (4) presence of initial weaknesses; (5) spacing of falling blocks; (6) persistence and strength of block discontinuities. In addition, working with fragmentation models also include the issues of (7) definition of threshold conditions for the fragmentation onset; (8) expected distribution of fragment sizes, and (9) the transfer of kinetic energy from the starting block to the fragments. Several authors noted that a complete understanding of the fragmentation process during rockfalls has not yet been achieved (Nocilla et al., 2008; Giacomini et al., 2009; Wang and Tonon, 2009; Frattini et al., 2012). 

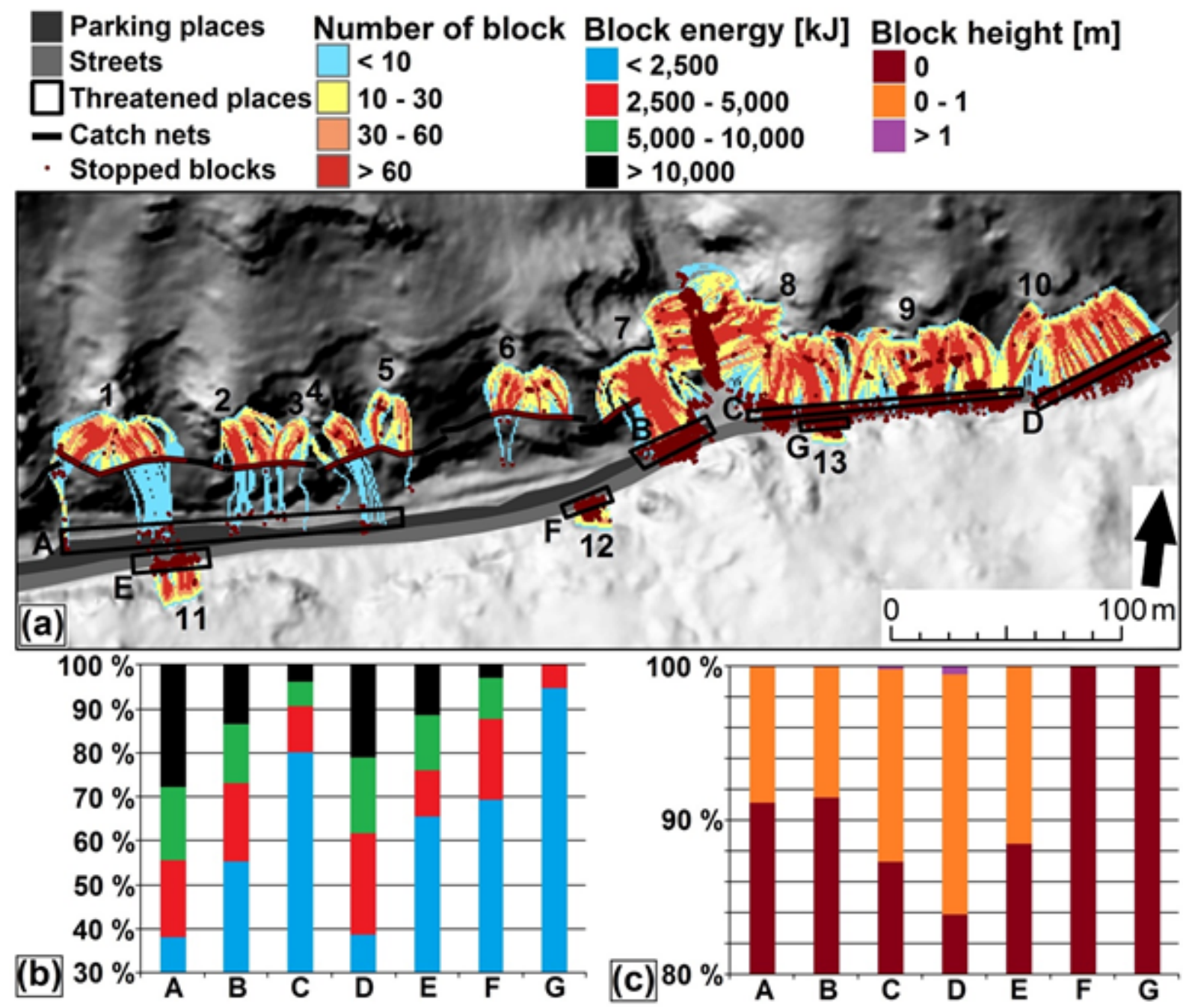

Fig. 10 Rockfall analysis around parking place and part of road going from Hřensko to Mezná city: (a) number of blocks; (b) kinetic energy of blocks [kJ]; and (c) block height [m].

\subsection{ROCKFALL COUNTERMEASURE DESIGN AND OPTIMIZATION}

The rockfall simulations showed that the effectiveness of barriers decreases dramatically when size and kinetic energy of the blocks increase, as expected. The barriers stopped $98 \%$ of falling blocks with radius $0.75 \mathrm{~m}$ and $63 \%$ of falling blocks with radius $1.5 \mathrm{~m}$ (Table 2 ). In all cases, the overcoming of the barrier is associated to a kinetic energy value of the block higher than the absorption energy of the barrier $(5,000 \mathrm{~kJ})$. In fact the blocks show a flight height lower than that of the barrier height $(4 \mathrm{~m})$.

Barriers built in Hřensko area belong to the category of rockfall flexible barriers, which are characterized by a high deformability of the interception structure and made from a high tensile wire mesh. These barriers consist of one main structure that bears the block impact, while the secondary meshwork is intended to arrest debris (Fig. 8c). Flexible barriers have become one of the most common measures, but their usage is limited by rockfall kinetic energy $(<8,000 \mathrm{~kJ})$ and trajectory height $(<8 \mathrm{~m})$ (Lambert and Bourrier, 2013; Crosta et al., 2015; Xu et al., 2018; Volkwein et al., 2019).
The simulation performed through HY-STONE showed some sectors where the blocks may threaten the Hřensko city (Fig. 8b). For a complete protection of dowslope areas during simulated rockfall events, some multiple barriers (kinetic energy $>5,000 \mathrm{~kJ}$ ) should be built in the sectors, where the blocks may pass through the existing barriers.

If the expected impact energy and/or high event frequency is too high for flexible (multiple) barriers, massive structural countermeasures are preferred: protective walls, large embankments or rock sheds (Lambert and Bourrier, 2013; Castanon-Jano et al., 2018). The choice of the optimal countermeasures depends first of all on a technical issue, which include assessing the most suitable typology, location and design to intercept all (or most) the possible rockfall events and to stand the related impact energies. However, the choice of the optimal countermeasures depends also on economic issue, which includes the evaluation of the cost-effectiveness and eventually the definition of a long-term maintenance program (Agliardi et al., 2009; Corona et al., 2017). The countermeasure and rockfall barriers design requires a quantitative assessment of rockfall hazard and risk 


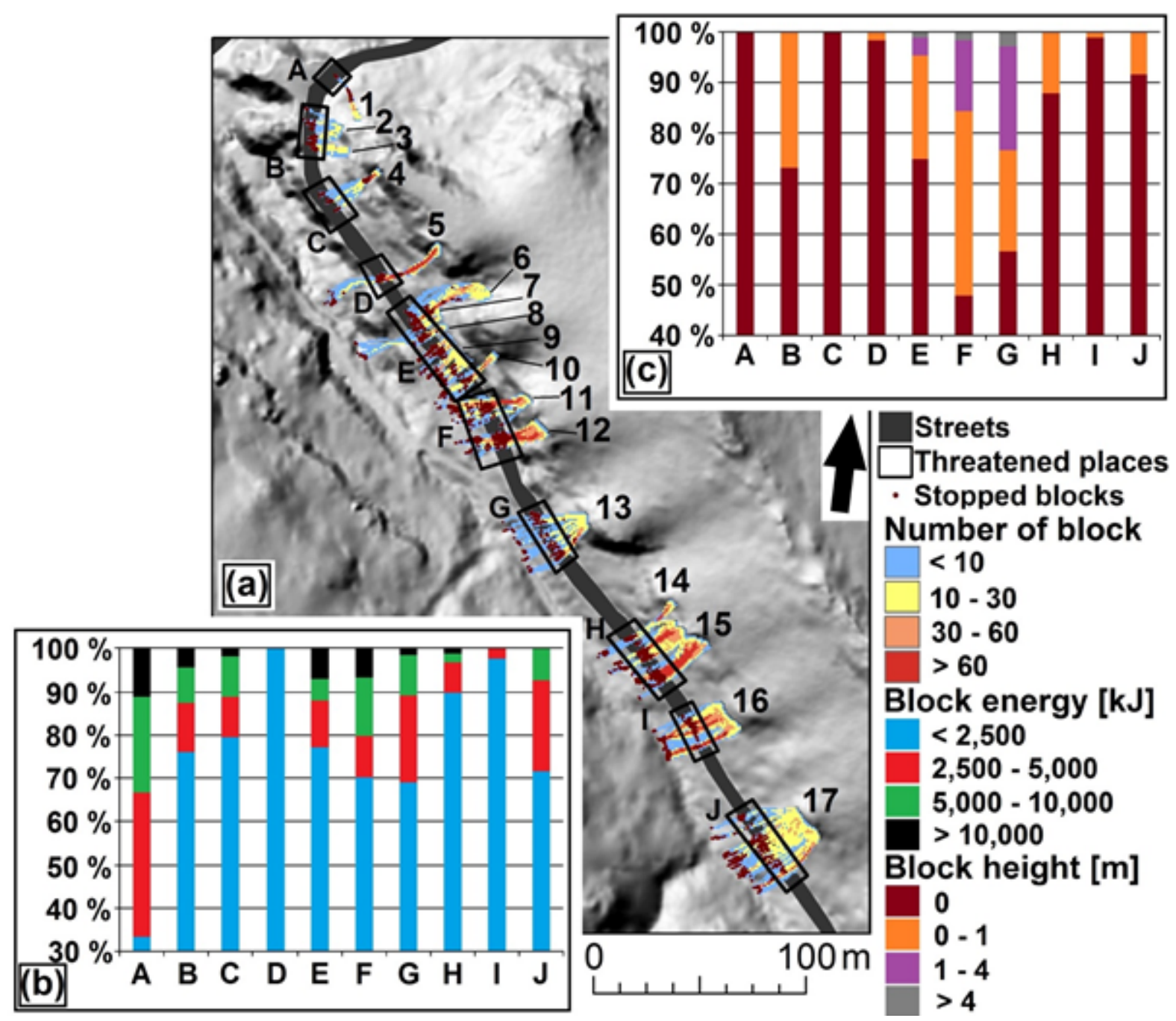

Fig. 11 Rockfall analysis around part of road going from Hřensko to Janov city: (a) number of blocks; (b) kinetic energy of blocks [kJ]; and (c) block height [m].

and the performing of complex cost-benefit analysis.

In addition, regular monitoring of detached blocks in source areas is as important as the costruction of the rockfall barriers. In the study area, an automatic monitoring system was installed, consisting of three basic parts: movement measuring sensor, data acquisition center and power supply for the measuring system, and online evaluation system. This automatic monitoring system with remote data transfer can produce information every second, if needed (Šafránek, 2016).

\subsection{COMPLEX ROCKFALL ANALYSIS OF THREE LOCATIONS IN HǨENSKO}

In the three different locations, blocks could threaten infrastructures in different ways, which suggested different mitigation strategies. The rockfall simulations in the parking place (first location Fig. 9) show that in every damaged road section some of the blocks can hit the roads with energy exceeding $5,000 \mathrm{~kJ}$ (Fig. 10b), potentially passing through other barriers. On the other hand, the height of blocks shows that they just rolled or jumped up to a height of
$1 \mathrm{~m}$ during the impacts to road (Fig. 10c). In these case, it would be useful to design an embankment as a more appropriate countermeasure for rockfall protection (according to Lambert and Bourrier, 2013; Castanon-Jano et al., 2018). The rockfall simulations in the part of road from Hrensko to Janov city (second location Fig. 9) show that the blocks do not exceed a height of $1 \mathrm{~m}$ during the impacts to road. This suggest that a low wall would protect the road efficiently, with the exception of blocks from source areas situated on a cliff close to road (marked as E, F, $\mathrm{G}$ in Fig. 11a), $25 \%$ of which have reached a height of $1-4 \mathrm{~m}$ (Fig. 11c), thus requiring specific countermeasures such as rockfall barriers. At least, the most appropriate countermeasure in the part of Gabrielina stezka hiking trail (third location Fig. 9) could be the installation of multiple barriers at different elevation along the slope.

However, the most important part of rockfall protection is still the prevention and regular monitoring of potentially unstable blocks in source areas. In the National Park area, 270 potential unstable blocks are monitored in 39 different locations by 


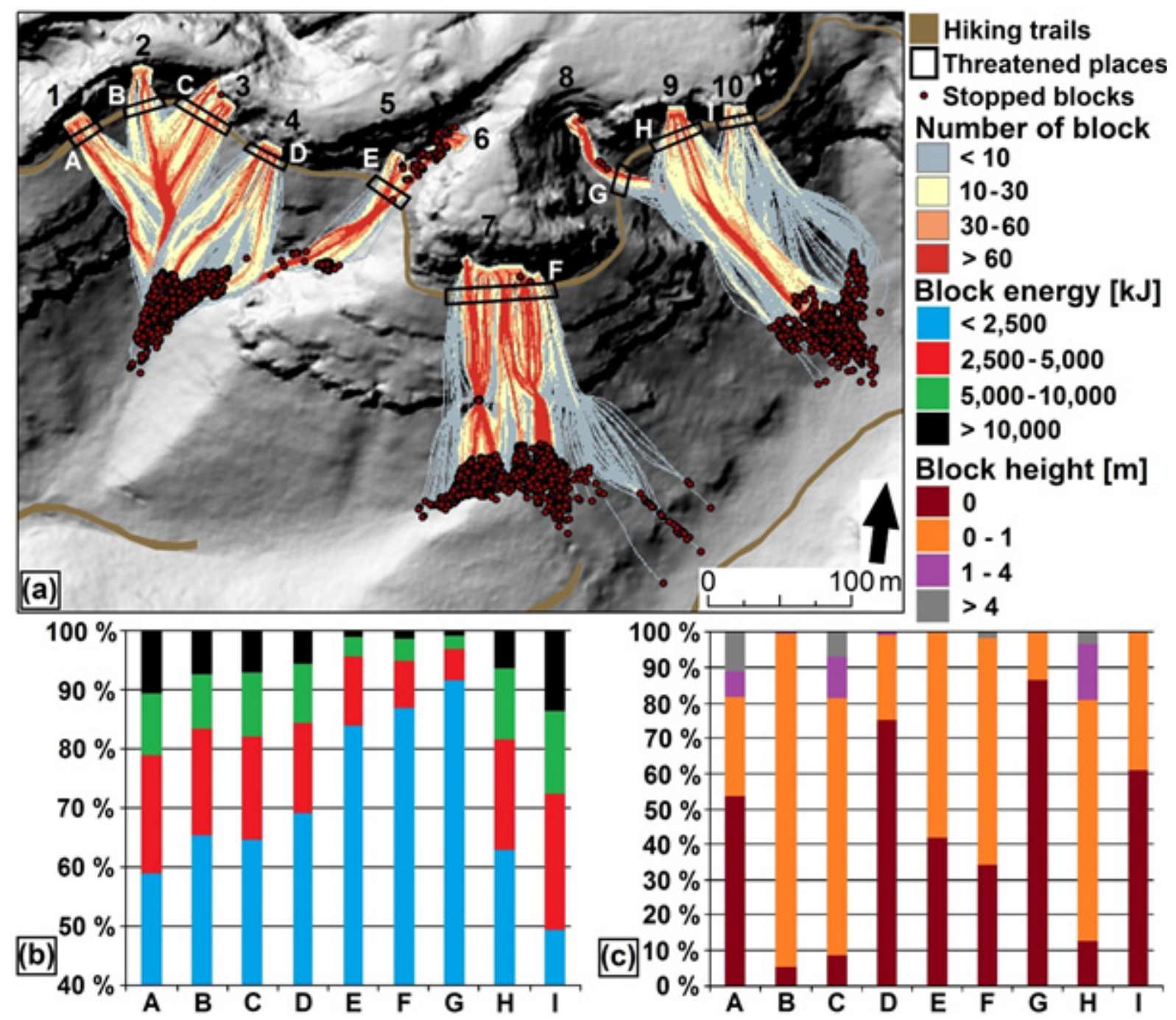

Fig. 12 Rockfall analysis around part of hiking trail Gabrielina stezka: (a) number of blocks; (b) kinetic energy of blocks [kJ]; and (c) block height [m].

using more than 500 measuring points (Šafránek, 2016). Each point is measured in a period ranging between 7 up to 14 days, depending on the hazard level.

\section{CONCLUSIONS}

$3 \mathrm{D}$ rockfall runout models are being used more often in rockfall assessment and risk redution. A larger number of rockfall studies and 3D modeling in the last years allows a comparison of results from many specific local study areas, which leads to an improving quality of the 3D modeling methodologies.

This study underlines the importance of hight quality data (e.g. DEM and input model data) for an accurate detection of rockfall sources and a better simulation of 3D trajectories of the blocks, distribution of kinetic energy and fly heights. In particular, the study shows how an accurate mapping of existing rockfall events is fundamental for a reliable calibration of model parameters, and how the results of the model are sensitive to the resolution of DEM. By using field surveyed rockfall data and a high-resultion DEM, it has been possible in this study to simulate the rockfall propagation with an accuracy of $92 \%$. This good result suggests that the model is able to reasonably reproduce the behaviour of actual blocks and their dynamics, making us confident on the reliability of the simulated scenarios.

Based on the calibrated 3D rockfall model it has been possible to simulate different rockfall countermeasures with different structural and technical characteristics. This is a very useful aspect that supports decision-making capabilities in areas affected by rockfall (such as the choice of the most suitable countermeasure, support for cost-benefit analysis, the optimal positioning of the countermeasure on the slope).

The continuous development in rockfall modeling is leading to the generation of tools that consider further more advanced aspects such as blocks fragmentation and the interaction with vegetation along the slope, for an increasingly optimal simulation of the phenomenon. These aspects were included in the test modeling and their effects of pixel size changing and fragmentation on rockfall trajectories and the trajectories, runout extent, velocities and relative heights of the falling blocks were described. 
At least it is undeniable the importance of careful field data collection and the evaluation by qualified professionals as support to rockfall 3D modeling. The increasing of model accuracy and their wider use in preactical applications lead to the need for more complex calibration, based on more and better field observations and stochastic approach. Each 3D rockfall model requires a different input data, assessment of rockfall sources, falling blocks and slope characteristics, and also specific model calibration. Users must be fully aware of the logic, advantages, and deficiencies of the rockfall models and the different modeling approaches should be evaluated against the scale and objective of the modeling.

Due to the annual high rockfall frequency in the Bohemian Switzerland National Park (BSNP), which may reach catastrophic proportions, further attention is needed on this topic. This article describes the possibilities of using $3 \mathrm{D}$ modeling in this area with reliable results. In the future, this methodology will be used for a complete rockfall analysis, which will lead to more accurate identifications of endangered sites in this area and to a reduction of the threat to isolated homes, entire villages, roads and other infrastructures.

\section{ACKNOWLEDGMENTS}

The study was supported by the Italian Ministry of International Affairs (Ministero degli Affari Esteri e della Cooperazione Internazionale). This work was carried out thanks to the support of the long-term conceptual development research organization RVO: 67985891. The work was partially supported by project “@RockHoRiZon - Advanced Tools for Rockfall Hazard and Risk zonation at the Regional Scale" funded by Fondazione Cariplo, grant 20160756. DEM and rockfall barriers information were provided by the Bohemian Switzerland National Park (BSNP).

\section{REFERENCES}

Agliardi, F. and Crosta, G.: 2003, High resolution threedimensional numerical modelling of rockfalls. Int. J. Rock Mech. Min., 40, 455-471.

DOI: 10.1016/S1365-1609(03)00021-2

Agliardi, F., Crosta, G.B. and Frattini, F.: 2009, Integrating rockfall risk assessment and countermeasure design by 3D modelling techniques. Nat. Hazards Earth Syst. Sci., 9, 1059-1073. DOI: 10.5194/nhess-9-1059-2009

Azzoni, A., La Barbera, G. and Zaninetti, A.: 1995, Analysis and prediction of rock falls using a mathematical model. Int. J. Rock Mech. Min. Sci. Geomech. Abstr., 32, 7, 709-724. DOI: 10.1016/0148-9062(95)00018-C

Blahůt, J., Klimeš, J. and Vařilová Z.: 2013, Quantitative rockfall hazard and risk analysis in selected municipalities of the České Švýcarsko National Park, Northwestern Czechia. Geografie, 118, 3, 205-220.

Castanon-Janoa, L., Blanco-Fernandeza, E., Castro-Fresnoa, D. and Ferreñob, D.: 2018, Use of explicit FEM models for the structural and parametrical analysis of rockfall protection barriers. Engineering Structures, 166, 212-226. DOI: 10.1016/j.engstruct.2018.03.064
Chau, K.T., Wong, R.H.C. and Wu, J.J.: 2002, Coeficient of restitution and rotational motions of rockfall impacts. Int. J. Rock Mech. Min., 39, 69-77. DOI: 10.1016/S1365-1609(02)00016-3

Corona, Ch, Lopez-Saez, J., Favillier, A., Mainieri, R., Eckert, N., Trappmann, D., Stoffel, M., Bourrier, F. and Berger, F.: 2017, Modeling rockfall frequency and bounce height from three-dimensional simulation process models and growth disturbances in submontane broadleaved trees. Geomorphology, 281, 66-77. DOI: 10.1016/j.geomorph.2016.12.019

Crosta, G.B. and Agliardi, F.: 2004, Parametric evaluation of 3D dispersion of rockfall trajectories. Nat. Hazard. Earth. Sys., 4, 583-598.

DOI: 10.5194/nhess-4-583-2004

Crosta, G.B., Frattini, P., Imposimato, S. and Agliardi, F.: 2006, Modeling vegetation and fragmentation effects on rockfalls. Geophys. Res. Abstr., 8, 76-94.

Crosta, G.B., Agliardi, F., Frattini, P., and Lari, S.: 2015, Key issues in rock fall modeling, hazard and risk assessment for rockfall protection. In: Lollino, G. et al. (eds.), Engineering Geology for Society and Territory, 2, 43-58.

Cruden, D.M. and Varnes, D.J.: 1996, Landslides types and processes. In: Turner, A.K. and Schuster, R.L. (Eds.), Landslides: Investigation and Mitigation. Transportation Research Board, 247, 36-71.

Czech Geology Survey: 1998, Geology map of Czech Republic, 1 : 50 000. In: Coubal, M. (Eds.), Český geologický ústav, Praha.

Dinçer, I., Orhan, A., Frattini, P., and Crosta, G., B.: 2014, Rock mass instabilities in Tatlarin Underground City (Cappadocia-Turkey). In: Lollino, G. et al. (Eds.), Engineering Geology for Society and Territory, 8, 361-369. DOI: 10.1007/978-3-319-09408-3

Dorren, L.K.A., Berger, F., Le Hir, C., Mermin, E. and Tardif, P.: 2005, Mechanisms, effects and management implications of rockfall in forests. Forest Ecol. Manag., 215, 183-195. DOI: $10.1016 /$ j.foreco.2005.05.01

Dorren, L.K.A., Berger, F. and Putters, U.S.: 2006, Real size experiments and 3D simulation of rockfall on forested and non-forested slopes. Nat. Hazard. Earth Syst. Sci., 6, 145-153. DOI: 10.5194/nhess-6-145-2006

Evans, D.L., Roberts, S.D., Mccombs, J.W. and Harrington, R.L.: 2001, Detection of regularly spaced targets in small-footprint LiDAR data: Research issues for consideration. Photogramm. Eng. Rem. Sens., 67, 10, 1133-1136.

Fanos, A.M. and Pradhan, B.: 2019, A novel rockfall hazard assessment using laser scanning data and 3D modelling in GIS. Catena, 172, 435-450. DOI: $10.1016 /$ j.catena.2018.09.012

Frattini, P., Crosta, G.B. and Agliardi, F.: 2012, Rockfall characterization and modeling. In: Clague, J.J., Stead, D., Landslides: Types, mechanisms and modeling. Cambridge University Press, 267-281.

Frattini, P., Crosta, G.B., Agliardi, F. and Imposimato, S.: 2013, Challenging calibration in 3D rockfall modelling. In: Margottini, C. et al. (Eds.): Landslide Science and Practice, 3, 169-175.

Fuhr, M., Bourrier, F. and Cordonnier, T.: 2015, Protection against rockfall along a maturity gradient in mountain forests. Forest Ecol. Manag., 354, 224-231. DOI: 10.1016/j.foreco.2015.06.012

Giacomini, A., Buzzi, O., Renard, B., Giani, G.P.: 2009, Experimental studies on fragmentation of rock falls on impact with rock surfaces. Int. J. Rock Mech. Min. 
Sci., 46, 708-715.

DOI: 10.1016/j.ijrmms.2008.09.007

Guzzetti, F., Crosta, G., Detti, R. and Agliardi, F.: 2002, Stone: A computer program for the three-dimensional simulation of rockfalls. Comput. Geosci., 28, 9, 10811095.

Kalvoda, J. and Zvelebil, J.: 1983, Dynamika a typy porušování svahů při vývoji údolí Labe v Děčínské vrchovině. Acta Montana, 63, 5-73, (in Czech).

Koukoulas, S. and Blackburn, G.A.: 2005, Mapping individual tree location, height and species in broadleaved deciduous forest using airborne LiDAR and multi-spectral remotely sensed data. Int. J. Remote Sens., 26, 3, 431-455.

DOI: $10.1080 / 0143116042000298289$

Labiouse, V. and Heidenreich, B.: 2009, Half-scale experimental study of rockfall impacts on sandy slopes. Nat. Hazard. Earth Syst. Sci., 9, 6, 1981-1993. DOI: 10.5194/nhess-9-1981-2009

Lambert, S. and Bourrier, F.: 2013, Design of rockfall protection embankments: A review. Eng. Geol., 154, 77-88. DOI: $10.1016 /$ j.enggeo.2012.12.012

Lan, H., Martin, C.D. and Lim, C.H.: 2007, RockFall analyst: A GIS extension for three-dimensional and spatially distributed rockfall hazard modeling. Comput. Geosci., 33, 2, 262-279.

DOI: $10.1016 /$ j.cageo.2006.05.013

Leine, R.I., Schweizer, A., Christen, M., Glover, J., Bartelt, P. and Gerber, W.: 2013, Simulation of rockfall trajectories with consideration of rock shape. Multibody Syst Dyn, 32, 1-31. DOI: $10.1007 / \mathrm{s} 11044-013-9393-4$

Loye, A., Jaboyedoff, M. and Pedrazzini, A.: 2009, Identification of potential rockfall source areas at a regional scale using a DEM-based geomorphometric analysis. Nat. Hazard. Earth Syst. Sci., 9, 1643-1653. DOI: 10.5194/nhess-9-1643-2009

Lundström, T., Jonsson, M., J., Volkwein, A. and Stoffel, M.: 2009, Reactions and energy absorption of trees subject to rockfall: A detailed assessment using a new experimental method. Tree Physiol., 29, 3, 345-359. DOI: $10.1093 /$ treephys/tpn030

Nocilla, N., Evangelista, A. and Scotto Di Santolo, A.: 2008, Fragmentation during rock falls: Two Italian case studies of hard and soft rocks. Rock Mech. Rock Eng., 42, 5, 815-833. DOI: $10.1007 / \mathrm{s} 00603-008-0006-0$

Olmedo, I., Bourrier, F., Bertrand, D., Berger, F. and Limam, A.: 2016, Discrete element model of the dynamic response of fresh wood stems to impact. Eng. Struct., 120, 13-22. DOI: 10.1016/j.engstruct.2016.03.025

Petránek, J., Březina, J., Bř́zová, E., Cháb, J., Loun, J. and Zelenka, P.: 2016, Encyklopedie geologie. Česká geologická služba, Praha, 349 pp., (in Czech).

Pfeiffer, T.J. and Bowen, T.D.: 1989, Computer simulations of rockfalls. Bull. Assoc. Eng. Geol., 26, 135-146.

Prisco, C. and Vecchiotti, M.: 2006, A rheological model for the description of boulder impacts on granular strata. Geotechnique, 56, 469-482. DOI: $10.1680 /$ geot.2006.56.7.469

Sass, O. and Oberlechner, M.: 2012, Is climate change causing increased rockfall frequency in Austria? Nat. Hazard. Earth Syst. Sci., 12, 3209-3216. DOI: $10.5194 /$ nhess-12-3209-2012
Sassa, K., Tsuchiya, S., Ugai, K., Wakai, A. and Uchimura, T.: 2009, Landslides: a review of achievements in the first 5 years (2004-2009). Landslides, 6, 4, 275-286. DOI: $10.1007 / \mathrm{s} 10346-009-0172-5$

Šafránek, J.: 2016, Monitoring svahových pohybů v NP České Švýcarsko. Ochrana př́rody, 1, 18-22, (in Czech).

Tyráček, J.: 2001, Upper Cenozoic fluvial history of the Bohemian Massif. Quaternary International, 79, 1, 3753. DOI: 10.1016/S1040-6182(00)00121-X

Valagussa, A., Frattini, P. and Crosta, G.B.: 2014, Earthquake-induced rockfall hazard zoning. Eng. Geol., 182, 213-225. DOI: 1016/j.enggeo.2014.07.009

Vařilová, Z. and Zvelebil, J.: 2007, Catastrophic and episodic events in sandstone landscapes: slope movements and weathering. In: Härtel, H., Cílek, V., Herben, T., Jackson, A., Williams R. (Eds.): Sandstone Landscapes, Academia, 115-128.

Vařilová, Z., Zvelebil, J., Hubatka, F., Beneš, V. and Frolka, J.: 2014, The application of non-destructive methods to assess the stability of the national nature monument of the Pravčická Brána Rock Arch, Czech Republic. AUC Geographica, 49, 1, 49-59.

Volkwein, A., Schellenberg, K., Labiouse, V., Agliardi, F., Berger, F., Bourrier, F., Dorren, L.K.A., Gerber, W. and Jaboyedoff, M.: 2011, Rockfall characterisation and structural protection - a review. Nat. Hazard. Earth Syst. Sci., 11, 2617-2651. DOI: 10.5194/nhess-11-2617-2011

Volkwein, A., Brügger, L., Gees, F., Gerber, W., Krummenacher, B., Kummer, P., Lardon, J., and Sutter, T.: 2018, Repetitive rockfall trajectory testing. Geosciences, 8, 88 . DOI: $10.3390 /$ geosciences 8030088

Volkwein, A., Gerber, W., Klette, J., Spescha, G.: 2019, Review of approval of flexible rockfall protection systems according to ETAG 027. Geosciences, 9, 1, 49. DOI: $10.3390 /$ geosciences 9010049

Wang, Y. and Tonon, F.: 2009, Discrete element modeling of impact fragmentation in rock fall analysis. In: Proceedings of the 43rd US Rock Mechanics Symposium and 5th U.S.-Canada Rock Mechanics Symposium, Asheville, NC, Paper 09-153.

Wong, R.H., Ho, K.W. and Chau, K.T.: 2000, Shape and mechanical properties of slope material effects on the coeficient of restitution on rockfall study. In: Proceedings of the 4th North American Rock Mechanics Symposium NARMS 2000, Seattle, 507514.

Wu, S.Z., Chau, K.T. and Yu, T.X.: 2004, Crushing and fragmentation of brittle spheres under double impact test. Powder Technol., 143-144, 41-55. DOI: 10.1016/j.powtec.2004.04.028

Yashima, S., Kanda, Y. and Sano, S.: 1987, Relationships between particle size and fracture energy or impact velocity. Powder Technol., 51, 3, 277-282. DOI: 10.1016/0032-5910(87)80030-X

Xu, H., Gentilinib, C., Yua, Z., Qia, X. and Zhaoa, S.: 2018, An energy allocation based design approach for flexible rockfall protection barriers. Eng. Struct., 173, 831-852. DOI: 10.1016/j.engstruct.2018.07.018 